\title{
Generation and phenotype of mice harboring a nonsense mutation in the $V 2$ vasopressin receptor gene
}

\author{
June Yun, ${ }^{1}$ Torsten Schöneberg, ${ }^{2}$ Jie Liu, ${ }^{1}$ Angela Schulz, ${ }^{2}$ Carolyn A. Ecelbarger, ${ }^{3}$ \\ Dominique Promeneur, ${ }^{4}$ Soren Nielsen, ${ }^{4}$ Hui Sheng, ${ }^{5}$ Alexander Grinberg, ${ }^{5}$ \\ Chu-xia Deng, ${ }^{6}$ and Jürgen Wess ${ }^{1}$
}

${ }^{1}$ Laboratory of Bioorganic Chemistry, National Institute of Diabetes and Digestive and Kidney Diseases, Bethesda, Maryland, USA

${ }^{2}$ Institut für Pharmakologie, Fachbereich Humanmedizin, Freie Universität, Berlin, Germany

${ }^{3}$ Division of Endocrinology and Metabolism, Department of Medicine, Georgetown University, Washington, DC, USA

${ }^{4}$ Department of Cell Biology, Institute of Anatomy, University of Aarhus, Aarhus, Denmark

${ }^{5}$ Laboratory of Mammalian Genes and Development, National Institute of Child Health and Human Development, Bethesda, Maryland, USA

${ }^{6}$ Laboratory of Biochemistry and Metabolism, National Institute of Diabetes and Digestive and Kidney Diseases, Bethesda, Maryland, USA

Address correspondence to: Jürgen Wess, National Institute of Diabetes and Digestive and Kidney Diseases, Laboratory of Bioorganic Chemistry, Building 8A, Room B1A-05, 8 Center Drive MSC 0810, Bethesda, Maryland 20892, USA. Phone: (301) 402-3589; Fax: (301) 480-3447; E-mail: jwess@helix.nih.gov.

June Yun is enrolled in the George Washington University/NIH Joint Graduate Genetics Program. Jie Liu's present address is: Department of Obesity Research, Merck Research Laboratories, Rahway, New Jersey, USA.

Received for publication December 14, 1999, and accepted in revised form October 25, 2000.

The V2 vasopressin receptor (V2R) plays a key role in the maintenance of a normal body water balance. To generate an in vivo model that allows the physiological and molecular analysis of the role of V2Rs in kidney function, we have created mouse lines that lack functional V2Rs by using targeted mutagenesis in mouse embryonic stem cells. Specifically, we introduced a nonsense mutation known to cause X-linked nephrogenic diabetes insipidus (XNDI) in humans (Glu242stop) into the mouse genome. V2R-deficient hemizygous male pups showed a decrease in basal urine osmolalities and were unable to concentrate their urine. These pups also exhibited an enlargement of renal pelvic space, failed to thrive, and died within the first week after birth due to hypernatremic dehydration. Interestingly, female mice heterozygous for the $V 2 R$ mutation showed normal growth but displayed an XNDI-like phenotype, characterized by reduced urine concentrating ability of the kidney, polyuria, and polydipsia. Western blot analysis and immunoelectron microscopic studies showed that the loss of functional V2Rs had no significant effect on the basal expression levels of aquaporin-2 and the bumetanide-sensitive $\mathrm{Na}-\mathrm{K}-2 \mathrm{Cl}$ cotransporter (BSC-1). The V2R mutant mice described here should serve as highly useful tools for the development of novel therapeutic strategies for the treatment of XNDI.

J. Clin. Invest. 106:1361-1371 (2000).

\section{Introduction}

In most mammals, including humans, the maintenance of a normal water balance is critically dependent on the renal actions of the antidiuretic hormone, 8 -arginine vasopressin (AVP) $(1,2)$. When the plasma osmolality increases above a critical level, AVP is released from the posterior pituitary gland into the bloodstream. AVP exerts its antidiuretic effect via binding to renal V2 vasopressin receptors (V2Rs), which are almost exclusively expressed in the principal cells of the renal collecting duct system (1-4). Ligand-occupied V2Rs activate the stimulatory $G$ protein, $G_{s}$, resulting in an increase in intracellular cAMP levels which, through a series of intermediate steps, eventually triggers the insertion of the aquaporin-2 (AQP2) water channel proteins into the luminal membrane of the principal cells $(2,5-7)$. Accumulation of AQP2 water channels in the luminal side of the principal cells enables the passive movement of water from the tubulus lumen (urine) into the kidney interstitium and eventually into the bloodstream.

The human and rat $V 2 R$ genes were first cloned in 1992 and shown to be localized to the long arm of the $\mathrm{X}$ chromosome at position Xq28 (8-10). Sequence analysis $(9,10)$ indicates that the $V 2 R$ protein is a typical member of the superfamily of $G$ protein-coupled receptors that are characterized by the presence of seven transmembrane domains. It is now well established that inactivating $V 2 R$ mutations cause a rare kidney disease known as X-linked nephrogenic diabetes insipidus (XNDI), an AVP-insensitive form of diabetes insipidus that is inherited in an X-linked recessive manner (11-15). Currently, more than 150 putative disease-causing $V 2 R$ mutations have been 
identified in more than 240 apparently independent families (for more information, see http://www.medcon.mcgill.ca/nephros). About $50 \%$ of these mutations are missense mutations; frameshift mutations due to nucleotide deletions or insertions represent about $25 \%$; and about $15 \%$ are nonsense mutations and large deletions. In-frame deletions or insertions and splice site mutations represent the remaining cases. Functional characterization of these mutant V2Rs expressed in cultured cells has shown that the different mutations frequently interfere with the proper trafficking of the V2R to the cell surface or their ability to bind AVP and/or activate the $\mathrm{G}_{\mathrm{s}}$ /adenylyl cyclase system (11-15).

Loss of V2R function in patients with XNDI interferes with water uptake in the renal collecting duct system, resulting in the production of large volumes $(>30$ $\mathrm{ml} / \mathrm{kg} / \mathrm{d}$ ) of dilute urine $\left(<250 \mathrm{mOsm} / \mathrm{kg} \mathrm{H}_{2} \mathrm{O}\right.$ ) (polyuria). These heavy water losses are accompanied by excessive thirst (polydipsia) and must be compensated by the intake of large quantities of water. In the case of inadequate water supply, polyuria can rapidly lead to severe conditions of hypernatremia and dehydration. Newborns suffering from XNDI frequently show poor weight gain and an overall failure to thrive, especially if XNDI is not properly diagnosed and treated (11-15). In at least some cases, patients with XNDI develop signs of mental retardation, most likely as the result of repeated episodes of dehydration (11-15). Moreover, such episodes of dehydration are thought to be responsible for chronic renal insufficiency which may occur by the end of the first decade of life due to thrombosis of the glomerular tufts $(16,17)$.

Current pharmacological treatment strategies of XNDI include the administration of thiazide diuretics (e.g., hydrochlorothiazide [HCT]) along with a reduction in salt intake, frequently in combination with prostaglandin synthesis inhibitors (e.g., indomethacin) or potassium-sparing diuretics (e.g., amiloride) $(14,15$, 18). However, these drugs only lead to a partial reduction in urine production (up to $50 \%$ ), and their use is often associated with severe side effects including disturbances in electrolyte balance, as well as renal and gastrointestinal complications (discussed in ref. 18).

At present, no animal model exists for XNDI. However, such a model should be highly useful for developing new strategies for the treatment of XNDI. Importantly, an in vivo model of XNDI would enable examination of the extent to which the loss of functional V2Rs affects the expression levels and function of other proteins that play key roles in urine concentration mechanisms. Currently, no such information is available for patients with XNDIs.

We therefore decided to use gene targeting technology to produce mouse lines lacking functional V2Rs. Specifically, a nonsense mutation (Glu242stop) known to cause XNDI in humans (19) was introduced into the $V 2 R$ coding sequence. A major reason why this particular mutation was chosen was that the encoded mutant receptor is retained intracellularly and is completely devoid of functional activity (20). The functional properties of the Glu242stop mutant V2R are therefore characteristic of most other disease-causing mutant V2Rs that have been identified to date (ref. 21 and references therein).

We report here an initial molecular, pharmacological, and physiological analysis of mutant mouse lines lacking functional V2Rs. Whereas V2R-deficient hemizygous mutant male pups died within the first week after birth due to hypernatremic dehydration, female mice heterozygous for the $V 2 R$ mutation showed normal growth but displayed an XNDI-like phenotype.

\section{Methods}

Generation of V2R mutant mice. A murine V2R clone was isolated from a mouse genomic library derived from strain 129/SvJ (Genome Systems Inc., St. Louis, Missouri, USA), by using a PCR fragment corresponding in sequence to amino acids $146-262$ of the mouse V2R as a probe. The amino acid sequence of the mouse V2R has been reported previously (22). Like its human counterpart (9), the mouse $V 2 R$ coding sequence consists of 371 amino acids and is interrupted by two small introns (Figure 1a). The V2R targeting construct (Figure 1a) was derived from the pPN2T vector (23), which is characterized by the presence of two copies of the herpes simplex virus thymidine kinase gene (HSV-TK). The PGK-neomycin resistance gene (neo) was inserted into the second intron that splits codon 304 . The neo cassette was flanked by two loxP sequences (24), $34 \mathrm{bp}$ in length, enabling the option of removing the neo gene from the mouse genome at a later point. The Glu242stop nonsense mutation $(\mathrm{GAA} \rightarrow \mathrm{TAG})$ was introduced by PCR-based sitedirected mutagenesis; during this procedure, a novel NheI site was created at the Glu242stop locus for diagnostic purposes (Figure 1a).

The targeting construct was linearized with NotI and electroporated into $129 \mathrm{SvEv}$ (TC1; ref. 25) or 129 R1 embryonic stem (ES) cells (26). G418- and ganciclovir-resistant clones were isolated and screened by Southern blotting for proper integration of the V2R targeting construct. Analysis of BamHI-digested DNA with an external $3^{\prime}$ probe was used to detect the presence of the neo cassette in the second intron (Figure 1a). Moreover, PCR analysis was conducted to confirm the presence of the Glu242stop mutation. Two primers were used that flank the newly created NheI/Glu242stop mutation: sense, 5'-TAGCATACCGCCATGGAGGT-3'; anti-sense, 5' - ATACATGGGCTCCCTCGCTGGG-3'; 30 cycles, $94^{\circ} \mathrm{C}$ for 30 seconds / $60^{\circ} \mathrm{C}$ for 30 seconds $/ 72^{\circ} \mathrm{C}$ for 1 minute. The resulting 350-bp PCR product was then digested with NheI. When the Glu242stop mutation is present, NheI digestion is expected to generate two cleavage products, 60 and $290 \mathrm{bp}$ in length. Using this strategy, eight properly targeted ES cell clones were identified (of a total of 260 clones that were screened). 
Properly targeted ES cell clones were microinjected into C57BL/ 6 mouse blastocysts to generate chimeric mice. Male chimeras were then mated with female wildtype CF-1 mice (Charles River Laboratories, Wilmington, Massachusetts, USA) to obtain F1 offspring. Female F1 mice heterozygous for the $V 2 R$ mutation were then crossed with wild-type male littermates to produce F2 offspring. Mice were genotyped in the same manner as already described here, using genomic tail DNA (Figure 1, b and c). Using this strategy, three independent $\mathrm{V} 2 \mathrm{R}$ mutant mouse lines originating from three independent ES cell clones were obtained.

Treatment of $V 2 R$-deficient pups. Hemizygous male mutant pups $\left(V 2 R^{-/ y}\right)$ lacking functional V2Rs died during the first week after birth. In an attempt to raise these pups to adulthood, they were treated with daily subcutaneous injections of $5 \%$ dextrose solution (0.1 $\mathrm{ml} / \mathrm{g}$ body weight per injection), starting from postnatal day 1 . Injections were carried out two (7-8 am and $10-11 \mathrm{pm})$ or three times a day (7-8 am, 3-4 pm, and $10-11 \mathrm{pm})$. In another set of experiments, pups were injected two or three times a day with different doses of HCT (Research Biochemicals International, Natick, Massachusetts, USA), either alone or in combination with different doses of indomethacin (Indocin I.V.; Merck Sharp \& Dohme, West Point, Pennsylvania, USA). Drugs were dissolved in 5\% dextrose solution and administered by subcutaneous injection $(0.1 \mathrm{ml} / \mathrm{g}$ body weight per injection).

Histological analysis of pup kidneys. Three-day-old mouse pups were sacrificed by cervical dislocation. Body cavities were opened, and pups were fixed in buffered zinc formalin (Z-fix; Anatech Ltd., Battle Creek, Michigan, USA). After fixation, both kidneys were removed; the right kidney was sectioned through the papilla in crosssection and the left kidney was sectioned longitudinally along the midline. These sections were embedded in paraffin blocks, and $5-\mu \mathrm{m}$-thick sections were cut on a microtome and stained with hematoxylin and eosin.

Urine output measurements and urine concentrating tests. Urine samples were obtained from 3-day-old pups and adult female mice (30-36 weeks old), either by direct collection of bladder contents or by bladder massage. Urine osmolalities were measured using a vapor pressure osmometer (5100c; Wescor Inc., Logan, Utah, USA). To measure urine production over a 24-hour period, adult female mice were placed in metabolic cages (Nalgene 6500311; Nalge Co., Rochester, New York, USA). For urine concentrating tests, adult female mice were thirsted for 24 hours (no access to water). In another set of experiments, 3-day-old mouse pups and adult female mice were injected with the V2R agonist, 1-desamino-8-D-arginine vasopressin (dDAVP; $0.4 \mu \mathrm{g} / \mathrm{kg}$, intraperitoneally). Urine was collected immediately before and about 2 hours after dDAVP administration.

Blood/serum measurements. For hematocrit, blood glucose, and serum electrolyte determinations, trunk blood was collected from 3-day-old pups or adult female mice (30-36 weeks old). Blood glucose levels were determined using a glucose dehydrogenase test (Granu-Test, EPOS 560; Merck KGaA, Darmstadt, Germany). Serum $\mathrm{Na}^{+}, \mathrm{Cl}^{-}$, and $\mathrm{K}^{+}$levels were determined on either a Hitachi 917 automatic analyzer (Hitachi Instruments, Ibari-Ken, Japan) or a COBAS Integra system (Roche Diagnostics, Mannheim, Germany).

$\left[{ }^{3} \mathrm{H}\right]$-AVP binding studies. Whole kidneys were collected from 3-day-old pups or adult female mice (30-36 weeks old), and membrane preparations were obtained essentially as described (4). In brief, whole kidney membrane preparations (300 $\mu$ g protein per tube) were incubated in a $0.3 \mathrm{ml}$ volume with increasing concentrations (0.125-4.0 nM) of [ $\left.{ }^{3} \mathrm{H}\right]$-AVP $(68.5 \mathrm{Ci} / \mathrm{mmol}$; NEN Life

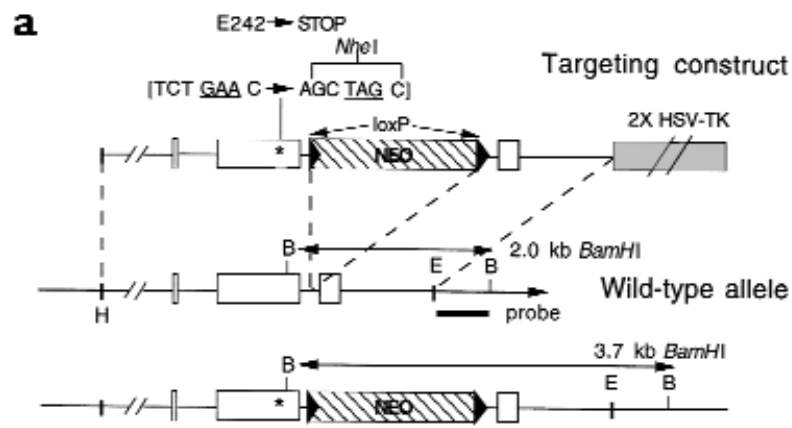

Mutant allele

b

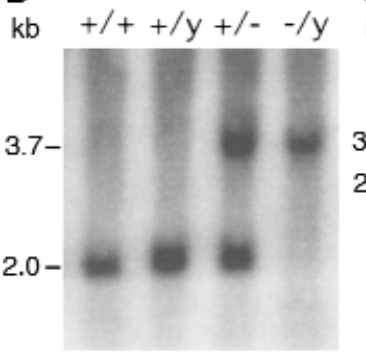

C

bp $+/++/-\quad-/ y-/ y+/ y$

Figure 1

Targeted mutagenesis of the mouse $V 2 R$ gene. (a) General strategy. The structures of the V2R targeting construct, the wild-type $V 2 R$ locus, and the targeted mutant $V 2 R$ allele are shown. $V 2 R$ coding sequences are depicted as open boxes. The neo cassette is represented by a hatched box, and the loxP sites are shown as arrows at either end of the neo cassette. The BamHI (b) sites used for Southern blot analysis and the sizes of the restriction fragments detected by using the 3' probe are indicated. The Glu242stop nonsense mutation $(\mathrm{GAA} \rightarrow \mathrm{TAG}$ ) that was introduced into exon 2 is represented by an asterisk. This nonsense mutation was generated in a fashion to introduce a novel Nhel site at the locus of Glu242stop mutation. The targeting construct contained approximately $6 \mathrm{~kb}\left(5^{\prime} \mathrm{arm}\right)$ and $1.4 \mathrm{~kb}$ ( $3^{\prime} \mathrm{arm}$ ) of genomic sequence, respectively. E, EcoRI; H, Hpal. (b) Genotyping of F2 mouse offspring via Southern blot analysis of BamHl-digested mouse tail DNA by using the 3' probe. The 3.7- and 2.0-kb bands represent the wild-type and mutant V2R alleles, respectively. (c) Verification of the presence of the Glu242stop mutation in F2 offspring using PCR analysis of genomic tail DNA, followed by Nhel digestion of the PCR product (for details, see Methods). The 350-bp band represents the uncut PCR product, indicative of the wild-type $V 2 R$ allele; the 290-bp fragment is produced by Nhel cleavage and is indicative of the mutant $V 2 R$ allele. The smaller Nhel cleavage product, $60 \mathrm{bp}$ in size, is not shown. 
Table 1

Weight, blood parameters, and urine osmolalities of 3-day-old mice of the indicated $V 2 R$ genotypes

\begin{tabular}{|c|c|c|c|}
\hline & $V 2 R^{+/+}, V 2 R^{+/ y}$ & $V 2 R^{+/-}$ & $V 2 R^{-/ y}$ \\
\hline \multicolumn{4}{|l|}{ Measurement } \\
\hline Weight (g) & $\begin{array}{c}2.39 \pm 0.51 \\
(n=70)\end{array}$ & $\begin{array}{l}2.30 \pm 0.50 \\
(n=41)\end{array}$ & $\begin{array}{c}1.64 \pm 0.20^{\mathrm{A}} \\
(n=36)\end{array}$ \\
\hline Hematocrit (\%) & $\begin{array}{c}30.6 \pm 0.3 \\
(n=9)\end{array}$ & $\begin{array}{l}29.1 \pm 0.9 \\
(n=8)\end{array}$ & $\begin{array}{c}35.0 \pm 0.9^{\mathrm{A}} \\
(n=10)\end{array}$ \\
\hline Serum $\mathrm{Na}^{+}(\mathrm{mmol} / \mathrm{l})$ & $\begin{array}{l}147 \pm 4 \\
(n=14)\end{array}$ & $\begin{array}{l}150 \pm 10 \\
(n=18)\end{array}$ & $\begin{array}{c}187 \pm 15^{\mathrm{A}} \\
(n=16)\end{array}$ \\
\hline Serum $\mathrm{Cl}^{-}(\mathrm{mmol} / \mathrm{l})$ & $\begin{array}{l}112 \pm 15 \\
(n=14)\end{array}$ & $\begin{array}{c}117 \pm 22 \\
(n=18)\end{array}$ & $\begin{array}{c}161 \pm 27^{\mathrm{A}} \\
(n=16)\end{array}$ \\
\hline Serum $\mathrm{K}^{+}(\mathrm{mmol} / \mathrm{I})$ & $\begin{array}{l}8.3 \pm 1.5 \\
(n=14)\end{array}$ & $\begin{array}{c}8.6 \pm 1.9 \\
(n=18)\end{array}$ & $\begin{array}{c}10.1 \pm 2.9 \\
(n=16)\end{array}$ \\
\hline Blood glucose $(\mathrm{mmol} / \mathrm{l})$ & $\begin{array}{c}6.2 \pm 1.4 \\
(n=29)\end{array}$ & $\begin{array}{l}5.8 \pm 0.1 \\
(n=14)\end{array}$ & $\begin{array}{c}3.0 \pm 0.8^{\mathrm{A}} \\
(n=17)\end{array}$ \\
\hline $\begin{array}{r}\text { Urine osmolalities } \\
\left(\mathrm{mOsm} / \mathrm{kg} \mathrm{H}_{2} \mathrm{O}\right)\end{array}$ & $\begin{array}{c}330 \pm 16 \\
(n=9)\end{array}$ & $\begin{array}{c}357 \pm 7 \\
(n=6)\end{array}$ & $\begin{array}{c}235 \pm 12^{\mathrm{A}} \\
(n=6)\end{array}$ \\
\hline
\end{tabular}

Data are given as means \pm SEM. The number of samples (pups) is given in parentheses. AValues of $V 2 R^{-1 y}$ mice that are significantly different from the corresponding values obtained with wild-type mice $\left(V 2 R^{+/+},+/ y\right) ; P<0.001$ (Student's $t$ test).

Science Products Inc., Boston, Massachusetts, USA) (20). Incubations were carried out for 1 hour at $25^{\circ} \mathrm{C}$. Nonspecific binding was defined as binding in the presence of $5 \mu \mathrm{M}$ unlabeled AVP. Binding data were analyzed by a nonlinear least squares curve-fitting procedure using the computer program LIGAND (27).

cAMP assays. Inner medulla collecting duct (IMCD) tubule suspensions were prepared from dissected mouse kidneys from adult female mice (30-36 weeks old) essentially as described elsewhere (28). Fiftymicroliter aliquots of IMCD tubule suspensions were incubated with increasing concentrations of dDAVP $(0-100 \mathrm{nM})$ in the presence of the cAMP phosphodiesterase inhibitor IBMX $(0.5 \mathrm{mM})$. Reactions were carried out at $37^{\circ} \mathrm{C}$ for 5 minutes and terminated by the addition of $200 \mu \mathrm{l}$ of $10 \%$ trichloroacetic acid. After centrifugation at 2,300 $\mathrm{g}$ for 10 minutes, cAMP was measured in the supernatant using an ELISA strategy (kit no. 581001; Cayman Chemical, Ann Arbor, Michigan, USA). Protein content of the pellet was determined by the Bradford method (Bio-Rad Laboratories Inc., Hercules, California, USA). cAMP data were analyzed using Prism (version 2.0; GraphPad Software Inc., San Diego, California, USA).

Immunoblotting studies. Whole kidneys were collected from 3-day-old pups or adult female mice (30-36 weeks old), immediately frozen on powdered dry ice, and stored at $-70^{\circ} \mathrm{C}$ until sample preparation. Plasma membrane-enriched fractions of whole kidney homogenates were prepared essentially as described previously (29). Samples containing $10 \mu \mathrm{g}$ protein were subjected to SDS-PAGE on $12.5 \%$ (AQP2) or $7.5 \%$ (BSC-1) polyacrylamide minigels. Proteins were transferred to nitrocellulose membranes via electroblotting and processed for immunoblotting essentially as described elsewhere (29). Membranes were blocked for 1 hour in 5\% milk in PBS with $0.05 \%$ Tween 20 (PBS-Tw) and probed overnight with affinity-purified rabbit polyclonal antibodies directed against rat AQP2 (L127, $0.03 \mu \mathrm{g} / \mathrm{ml}$; ref. 30) or rat BSC-1 (L320, $0.02 \mu \mathrm{g} / \mathrm{ml}$; ref. 31) (antibodies were kindly provided by M.A. Knepper). Blots were washed in PBS-Tw, then incubated for 1 hour with a goat anti-rabbit IgG antibody conjugated to horseradish peroxidase (Pierce 31460; Pierce Chemical Co., Rockford, Illinois, USA). Proteins were visualized by using an enhanced chemiluminescence kit (Amersham Pharmacia Biotech, Piscataway, New Jersey, USA). The intensities of immunoreactive bands were quantitated via scanning densitometry using NIH Image (version 1.61; NIH, Bethesda, Maryland, USA).

Immunoelectron microscopical studies. Kidneys from adult female mice (30-36 weeks old) were processed for immunoelectron microscopical studies as described previously (32). Ultrathin Lowicryl HM20 sections of mouse IMCD tissue were first incubated with the affinity-purified anti-AQP2 antibody, followed by incubation with goat anti-rabbit IgG conjugated to $10 \mathrm{~nm}$ colloidal gold particles (GAR.EM10 [1:50]; BioCell Research Laboratories, Cardiff, United Kingdom) (for experimental details, see ref. 32). Sections were stained with uranyl acetate and lead citrate before examination in Philips CM100 or Philips 208 electron microscopes (FEI Co., Eindhoven, The Netherlands).

\section{Results}

Generation of V2R-deficient mice. The V2R gene was inactivated in mouse ES cells by introducing a Glu242stop nonsense mutation into the $V 2 R$ coding region (Figure 1a). This mutation results in a V2R protein that is truncated within the third intracellular loop and is known to be functionally inactive (20). ES cell clones carrying the Glu242stop mutation were used to generate chimeric mice. Chimeric males were then crossed with CF-1 female mice to generate F1 females heterozygous for the $V 2 R$ mutation. F1 female heterozygotes $\left(V 2 R^{+-}\right)$were interbred with wild-type male littermates to obtain F2 offspring. Genotypes were verified by Southern blot analysis and PCR of genomic tail DNA (Figure 1, b and c).

Genotype analysis of more than 100 litters (F2 offspring) showed that V2R-deficient hemizygous $V 2 R^{-1 y}$ male mutant pups and heterozygous $V 2 R^{+/-}$female pups were obtained at the expected mendelian frequency $(\sim 25 \%)$, indicating that there was no increase in embryonic mortality in the $V 2 R$ mutant mice. Unless indicated otherwise, all studies described here were carried out with 129SvEv/CF-1 hybrids (F2 offspring).

$V 2 R^{-1 y}$ mice die prematurely. At birth, the body weight of $V 2 R^{-1 y}$ male mutant pups was similar to that of their wild-type (male $V 2 R^{+/ y}$; female $V 2 R^{+/+}$) or heterozygous $\left(V 2 R^{+/-}\right)$female littermates $(1.5-1.6 \mathrm{~g} ; n=43)$. Also, $V 2 R$ mutant pups showed no obvious morphological or anatomical abnormalities immediately after birth. However, by postnatal day $3, V 2 R^{-/ y}$ pups showed a clear retardation in growth $(\sim 30 \%$ decrease in body weight; Table 1), became progressively weaker, and 


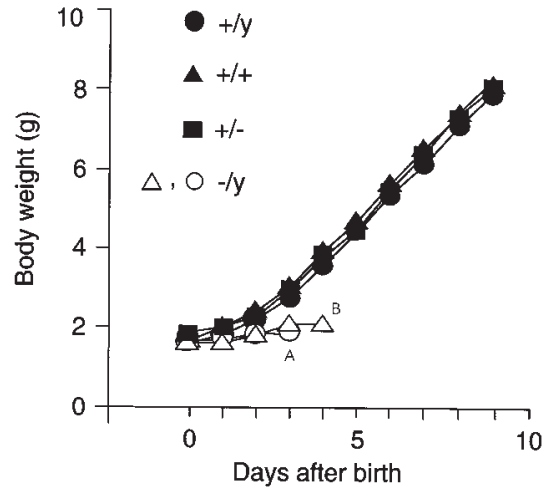

Figure 2

Postnatal growth of wild-type and $V 2 R$ mutant pups. Ten-day growth curves for individual pups from a representative litter are shown. The different $V 2 R$ genotypes are indicated. Animals were weighed at 24hour intervals starting from the day of birth (day 0 ). In this case, the two V2R-deficient male $V 2 R^{-/ y}$ mouse pups were found dead on ${ }^{A}$ postnatal day 4 or ${ }^{B}$ postnatal day 5 .

eventually died within the first week after birth (Figure 2). The average lifetime of the $V 2 R^{-1 y}$ pups amounted to $4.3 \pm 0.3$ days $(n=43)$. Premature death of $V 2 R^{-1 y}$ pups was observed with three independent $V 2 R$ mutant mouse lines originating from three different ES cell clones (either TC1 [129SvEv] or R1) and occurred independent of the mouse genetic background in which the $V 2 R$ receptor mutation was present (129/CF-1 or 129/C57BL6J) (data not shown).

Gross anatomical analysis of 3-day-old male mutant pups showed that the lack of functional V2Rs did not interfere with the normal development of all major organs (e.g. brain, liver, heart, lung, or kidneys), except for a reduction in organ size (weight) that was proportional to the reduction of total body weight (data not shown).

$V 2 R^{-1 y}$ mice show symptoms of XNDI. It seemed reasonable to assume that the $V 2 R^{-1} y$ mutant mice suffer from XNDI and die prematurely because of excessive water losses due to their inability to concentrate their urine. To address this issue, we initially determined urine osmolalities by collecting the bladder contents of 3day-old pups (all possible V2R genotypes). Urine osmolalities of 3-day-old pups were generally low $(<500$ $\mathrm{mOsm} / \mathrm{kg}$ ), consistent with previous observations that the urine-concentrating ability of the kidney is not yet fully developed in neonates (33). However, compared with their wild-type and heterozygous littermates, $V 2 R^{-1 y}$ mutant pups showed an approximately 30\% reduction in urine osmolality (Table 1).

Serum electrolyte analysis showed that the $V 2 R^{-1 y}$ pups displayed a pronounced increase in serum $\mathrm{Na}^{+}$and serum $\mathrm{Cl}^{-}$levels, compared with wild-type or heterozygous littermates (Table 1), indicative of a severe state of hypernatremia. In contrast, serum $\mathrm{K}^{+}$levels were similar in all pups, independent of $V 2 R$ genotype (Table 1 ).

To study the ability of the 3-day-old pups to concentrate their urine, wild-type and V2R mutant pups were injected with the V2R agonist dDAVP $(0.4 \mu \mathrm{g} / \mathrm{kg}$, intraperitoneally). Urine osmolalities were determined immediately before and about 2 hours after dDAVP administration. Whereas dDAVP injection led to a small but significant increase ( $20 \%$ above preinjection levels) in urine osmolalities in wild-type and $V 2 R^{+/-}$pups, $V 2 R^{-/ y}$ pups proved to be completely unresponsive to dDAVP treatment (Table 2). dDAVP administration had no significant effect on serum electrolyte levels in wildtype or V2R mutant pups (data not shown).

We also noted that the hematocrit was significantly increased in $V 2 R^{-1 y}$ pups (by about $15-20 \%$ ), compared with their wild-type and heterozygous littermates (Table 1). Moreover, the skin of the $V 2 R^{-1 y}$ pups appeared extremely dry, indicative of reduced skin turgor. Taken together, these observations support the notion that the $V 2 R^{-1 y}$ mice were severely dehydrated.

It appeared likely that the general weakness associated with hypernatremia and dehydration would negatively affect the ability of the $V 2 R^{-1 y}$ mutant mice to compete for the mother's milk. As an indirect measure of milk intake, we therefore determined blood glucose levels in wild-type and V2R mutant pups. Strikingly, blood glucose levels were approximately $50 \%$ lower in $V 2 R^{-1} y$ mutant pups than in wild-type or heterozygous littermates (Table 1).

Histological analysis of pup kidneys. To examine whether the loss of functional V2Rs had an effect on kidney architecture, kidney slices were prepared from 3-dayold pups and subjected to further histological analysis. These studies showed (Figure 3) that the pelvic space was significantly dilated in the case of ${\mathrm{V} 2 \mathrm{R}^{-1} \mathrm{y}}^{-}$ male mutant pups, compared with their wild-type $\left(V 2 R^{+/ y}\right)$ male littermates $(n=3)$. Female pups $\left(V 2 R^{+/-}\right.$ and $V 2 \mathrm{R}^{+++}$) did not show this enlargement of renal pelvic space $(n=3)$.

Strategies used to improve the survival rate of $V 2 R^{-1 y}$ pups. Several strategies were employed in an attempt to prolong the life span of the $V 2 R^{-1 y}$ pups. Reduction in litter size by removal of wild-type and heterozygous littermates and/or addition of foster mothers to increase the available milk supply did not improve the survival time of the $V 2 R^{-/ y}$ mutant pups to a significant extent (data shown). However, daily subcutaneous injections of a $5 \%$ dextrose solution $(0.1 \mathrm{ml} / \mathrm{g}$ body weight per

\section{Table 2}

Urine-concentrating ability of 3-day-old pups of the indicated $V 2 R$ genotypes determined in dDAVP injection experiments

\begin{tabular}{lccc}
\hline & \multicolumn{3}{c}{ Urine osmolalities $(\mathrm{mOsm} / \mathrm{kg} \mathrm{H} \mathrm{O})$} \\
& $V 2 R^{+/+}, V 2 R^{+/ y}$ & $V 2 R^{+/-}$ & $V 2 R^{-/ y}$ \\
Before dDAVP & $427 \pm 31$ & $486 \pm 58$ & $290 \pm 21$ \\
& $(n=13)$ & $(n=6)$ & $(n=7)$ \\
After dDAVP & $499 \pm 38^{\mathrm{A}}$ & $603 \pm 64^{\mathrm{A}}$ & $290 \pm 30$ \\
$(0.4 \mu \mathrm{g} / \mathrm{kg}$, intraperitoneally) & $(n=13)$ & $(n=6)$ & $(n=7)$ \\
& & & \\
\hline
\end{tabular}

Urine samples were collected (via bladder massage) immediately before and 2 hours after dDAVP injection. Data are given as means $\pm \operatorname{SEM}(n=$ number of animals). APostinjection values that are significantly different from the corresponding preinjection values $(P<0.05$; Student's $t$ test $)$. 


\section{Figure 3}

Histological appearance of kidneys from 3-day-old wildtype and $V 2 R$ mutant pups. Right kidneys from wild-type $(+/ y)(\mathbf{a})$ or V2R-deficient $(-/ y)(\mathbf{b})$ male pups were sectioned through the papilla in cross-section. Five$\mu \mathrm{m}$-thick sections were stained with hematoxylin and eosin. The bar in a corresponds to $0.4 \mathrm{~mm}$. Note that the pelvic space $(\mathrm{Pe})$ is greatly enlarged in kidneys from $V 2 R^{-1 y}$ mice. Cx, cortex; $\mathrm{Pa}$, papilla; $\mathrm{Pe}$, renal pelvis.

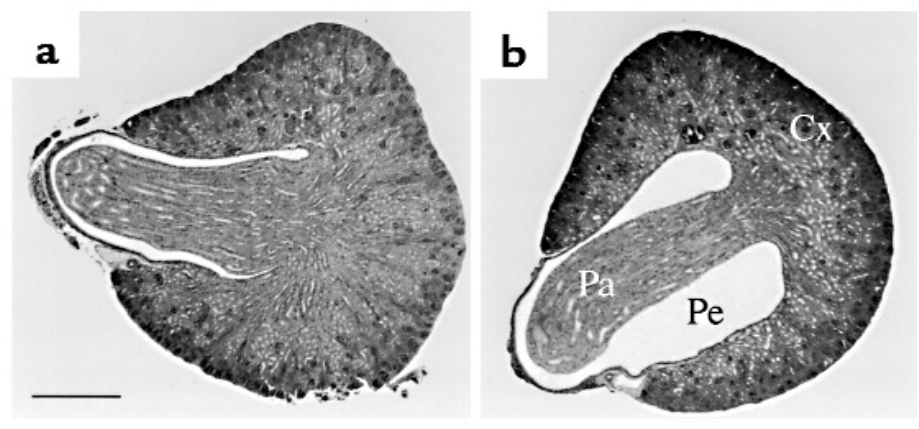

injection; three injections per day starting from postnatal day 1) led to a significant increase of the average lifetime of the $V 2 R^{-/ y}$ mutant pups to $13.7 \pm 1.0$ days (Table 3). Additional administration of HCT $(50 \mathrm{mg} / \mathrm{kg}$ day, subcutaneously), a drug commonly used in the treatment of XNDI, or combined administration of HCT and indomethacin ( 50 and $2 \mathrm{mg} / \mathrm{kg}$, respectively, daily, subcutaneously) had no significant effect on the life span of the mutant pups, compared with animals treated with dextrose alone (Table 3). Similarly, the use of higher doses of HCT (up to $100 \mathrm{mg} / \mathrm{kg}$ daily) and indomethacin (up to $10 \mathrm{mg} / \mathrm{kg}$ daily) did not lead to a further increase in survival time of the $V 2 R^{-1 y}$ mutant pups (data not shown).

Removal of the neo gene from V2R mutant mice. To rule out the possibility that the presence of the neo cassette in the mouse genome might contribute to the premature death of the $V 2 R^{-1 y}$ mutant mice by some unknown mechanism, we took advantage of the availability of a transgenic mouse line referred to as EIIa-cre (34). These mice harbor the cre transgene under the control of the adenovirus EIIa promoter that directs the expression of Cre recombinase during early development (34). To remove the loxP-flanked neo cassette (Figure 1a) from the genome of the $V 2 R$ mutant mice, homozygous male EIIa-cre mice were bred with female ${\mathrm{V} 2 \mathrm{R}^{+} /-}_{\text {mutant mice. }}$ Tail DNA obtained from the resulting pups was then examined via PCR genotyping using two internal neo primers (sense, $5^{\prime}$ agaggctattcggctatgactg- $3^{\prime}$; antisense, $5^{\prime}$-ttcgtccagatcatcctgatc- $3^{\prime}$ ) for the loss of the neo gene. Female $\mathrm{V} 2 \mathrm{R}^{+/}$offspring judged by tail DNA analysis as having lost the neo gene were then interbred with wildtype male littermates to achieve germline transmission of the neo deletion (Figure 4).

Analysis of the viability of the resulting pups showed that all male $V 2 R^{-1 y}$ pups lacking the neo cassette died within the first week after birth. The average lifetime of these mice amounted to $4.2 \pm 0.3$ days $(n=29)$, which was not significantly different from that observed with neo-containing male pups of the same $V 2 R$ genotype (see earlier discussion here).

Examination of adult heterozygous V2R mutant mice. In contrast to the $V 2 R^{-1 y}$ male pups, heterozygous $V 2 R^{+/}$ female pups showed normal postnatal growth (Figure 2 ) and developed normally into adulthood without an increase in mortality. Also, adult $V_{2} \mathrm{R}^{+/-}$and $V 2 \mathrm{R}^{+/+}$ female mice (30-36 weeks old) did not differ significantly in serum electrolyte, blood glucose, and hematocrit levels (data not shown).

To study whether adult female $V 2 R^{+/-}$mutant mice showed symptoms of XNDI, we initially measured water intake and urine production over a 24-hour period. As shown in Table 4, $V 2 R^{+/-}$mice drank about two times more water and produced about three times more urine than did their wild-type $V 2 R^{+/+}$littermates.

We next examined the ability of $V 2 \mathrm{R}^{+/-}$and $V 2 \mathrm{R}^{+/+}$ adult female mice to concentrate their urine by measuring urine osmolalities immediately before (basal) and after a 24-hour thirst period. These studies showed that basal urine osmolalities of $V 2 R^{+/-}$mice were reduced by more than $50 \%$ (Table 4). Upon thirsting, urine osmolalities increased to $3,700 \pm 9$ $\mathrm{mOsm} / \mathrm{kg}$ in wild-type mice, but to only $1,970 \pm 108$ $\mathrm{mOsm} / \mathrm{kg}$ in $V 2 \mathrm{R}^{+/-}$mice. In agreement with this

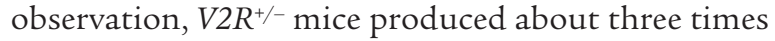

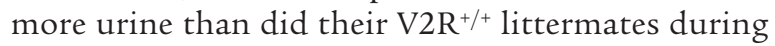
the 24-hour thirst period (Table 4). Essentially similar results were obtained in dDAVP $(0.4 \mu \mathrm{g} / \mathrm{kg}$, intraperitoneally) injection experiments (urines were collected immediately before and 2 hours after dDAVP injection). Whereas dDAVP administration increased urine osmolalities to $3,584 \pm 16 \mathrm{mOsm} / \mathrm{kg}$ in wild-type animals, urine osmolalities reached only 1,767 \pm 230 $\mathrm{mOsm} / \mathrm{kg}$ in $V 2 R^{+/-}$mice (Table 4).

$\left[{ }^{3} H\right] A V P$ saturation binding studies and $c A M P$ assays. The most likely explanation for the reduction in urine-con-

\section{Table 3}

Treatment of $V 2 R^{-/ y}$ male pups

\section{Treatment} Days alive (range)

No treatment $(n=4)$

$5 \%$ dextrose $(n=7)$

$50 \mathrm{mg} / \mathrm{kg} / \mathrm{d} \mathrm{HCT}(n=7)$

$50 \mathrm{mg} / \mathrm{kg} / \mathrm{d} \mathrm{HCT}+2 \mathrm{mg} / \mathrm{kg} / \mathrm{d}$ indomethacin $(n=10)$

$$
4.0 \pm 0.6(3-5)
$$

$13.7 \pm 1.0^{\mathrm{A}}(11-19)$

$16.5 \pm 1.5^{\mathrm{A}}(13-22)$

$10.1 \pm 1.5^{\mathrm{A}}(6-19)$

Male $V 2 R^{-/ y}$ mutant pups were injected subcutaneously three times a day $(0.1$ $\mathrm{ml} / \mathrm{g}$ per injection) with the indicated solutions/drugs, starting from postnatal day 1 . Injections were carried out according to the protocol described in Methods. Drugs were dissolved in 5\% dextrose solution. Data are given as means $\pm \operatorname{SEM}(n=$ number of animals used). All treatment strategies led to a significant increase in the survival time of the pups, compared with untreated control mice (AP $<0.01$; Student's $t$ test). 


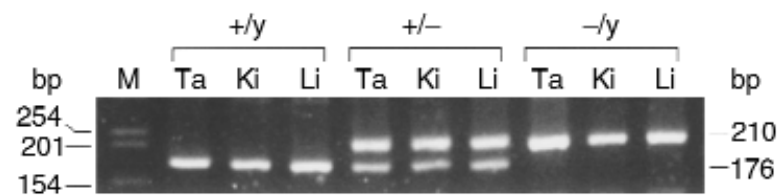

Figure 4

PCR analysis of genomic DNA prepared from tissues of $V 2 R$ mutant mice to verify Cre-mediated excision of the neo gene. Homozygous male Ella-cre mice were bred with female $V 2 R^{+/-}$mutant mice. Resulting $V 2 R^{+/-}$female offspring were then interbred with wild-type male littermates to achieve germline transmission of the neo deletion. To verify the ablation of the neo gene, genomic DNA was prepared from tail (Ta), kidney (Ki), and liver ( $\mathrm{Li}$ ) samples derived from the resulting pups and subjected to PCR genotyping. The two PCR primers used for this analysis were chosen to flank the loxP-enclosed neo cassette and were located at the exon 2 /intron 2 ( $5^{\prime}$-gaagctcctctggaaagtggt-3') and intron 2/exon 3 ( $5^{\prime}$-tcctatgaagaagagagaccag- $\left.3^{\prime}\right)$ junctions (see Figure 1a), respectively. After Cre-mediated excision of the neo gene (note that one 34-bp loxP sequence remains in the genome after the excision of the neo cassette), the two primers amplify a 210-bp PCR fragment, whereas the corresponding wildtype fragment is $34 \mathrm{bp}$ shorter (176 bp). The absence of neo sequences in all samples was confirmed by the use of internal neo primers (data not shown). The DNAs analyzed here were taken from three different mouse pups of the indicated $\mathrm{V} 2 \mathrm{R}$ genotypes.

centrating ability found with the $V 2 \mathrm{R}^{+/}$- female mice is that V2R levels are predicted to be decreased by $50 \%$ in these animals. To address this question, $\left[{ }^{3} \mathrm{H}\right]$ AVP saturation binding studies were carried out using whole kidney membrane preparations. Kidney preparations from adult $V 2 R^{+/+}$female mice were found to contain about $29 \pm 4 \mathrm{fmol}\left[{ }^{3} \mathrm{H}\right]$ AVP binding sites/mg protein $\left(\mathrm{B}_{\max }\right)(n=12)$. These sites appear to represent almost exclusively V2Rs, as shown in competition binding studies using $\mathrm{V} 1$ and $\mathrm{V} 2$ receptor selective unlabeled ligands (data not shown). In $V 2 R^{+/-}$females, $\left[{ }^{3} \mathrm{H}\right] \mathrm{AVP}$ $\mathrm{B}_{\max }$ values were reduced by about 50\% (16 \pm 3 $\mathrm{fmol} / \mathrm{mg} ; n=12 ; P<0.05)$. As expected, $\left[{ }^{3} \mathrm{H}\right]$ AVP $\mathrm{K}_{\mathrm{d}}$ values remained unaffected by the differences in V2R den-

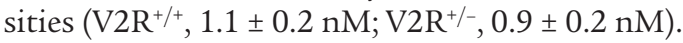

We next examined whether the decrease in renal V2R levels observed with adult $V 2 R^{+/-}$female mice was associated with a reduction in V2R-mediated cAMP production. Specifically, we prepared IMCD tubule suspensions (28) from kidneys of adult $V 2 R^{+/+}$and $V 2 R^{+/-}$ female mice and measured dDAVP-induced increases in intracellular cAMP levels. As shown in Figure 5, maximum cAMP responses were reduced by about $50 \%$ in IMCD tubule suspensions prepared from $V 2 R^{+/-}$mice. dDAVP $\mathrm{EC}_{50}$ values did not differ significantly among

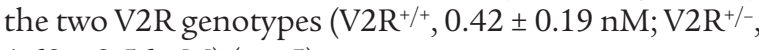
$1.60 \pm 0.56 \mathrm{nM})(n=5)$.

Expression of V2R-regulated effector proteins in V2R mutant mice. Recent reports indicate that V2R activity can regulate the expression levels of several effector proteins that play key roles in urine concentration, including AQP2 (reviewed in refs. 35-37) and the bumetanide-sensitive Na-K-2Cl cotransporter (BSC-1) (31), which is primarily expressed in cells of the thick ascending limb of Henle's loop (38). We therefore wanted to examine whether the loss of functional V2Rs had an effect on the basal expression levels of AQP2 and BSC-1 in the V2R mutant mice. Initially, Western blotting experiments were carried out with membrane preparations obtained from whole kidneys of 3-day-old pups or adult female mice (Figure 6). Immunoblots probed with a polyclonal AQP2 antibody revealed a single band at approximately $29 \mathrm{kDa}$ (representing nonglycosylated AQP2) and a broader band at $35-50 \mathrm{kDa}$ (corresponding to glycosylated forms of AQP2) $(30,31,39)$, whereas the polyclonal BSC-1 antibody detected a major band of approximately $160 \mathrm{kDa}$ (31). Scanning densitometry of immunoreactive bands indicated that $V 2 R^{-1 y}$ pups showed AQP2 or BSC-1 levels that were not significantly different from the corresponding levels found with their wild-type $V 2 R^{+/ y}$ male littermates (Figure 6a). Similarly, densitometric analysis did not reveal significant differences in AQP2 and BSC-1 expression levels among adult wild-type and heterozygous female mice (Figure 6b).

To study the expression of the AQP2 water channel in greater cellular detail, immunoelectron microscopical studies were carried out using IMCD tissue prepared from adult $V 2 R^{+/+}$and $V 2 R^{+/-}$female mice. This analysis revealed no major differences in the AQP2 labeling patterns among the two genotypes. As shown in Figure 7, AQP2 immunogold labeling was associated with the apical plasma membrane (arrows) and intracellular vesicles (arrowheads) in wild-type (Figure 7a) and heterozygous (Figure $7 \mathrm{~b}$ ) mice. Immunolabeling controls (preabsorption of the immune serum with the peptide

\section{Table 4}

Water intake, urine output, and urine-concentrating ability of adult female mice of the indicated $V 2 R$ genotypes

\begin{tabular}{lcc}
\hline & $V 2 R^{+/+}$ & $V 2 R^{+/-}$ \\
Water intake per 24 hours $(\mathrm{ml})$ & $2.3 \pm 0.1$ & $5.0 \pm 1.1^{\mathrm{A}}$ \\
& $(n=15)$ & $(n=15)$ \\
& $0.8 \pm 0.1$ & $2.6 \pm 0.8^{\mathrm{A}}$ \\
Urine output per 24 hours $(\mathrm{ml})$ & $(n=15)$ & $(n=15)$ \\
(free access to water) & $0.29 \pm 0.07$ & $0.89 \pm 0.21^{\mathrm{A}}$ \\
Urine output per 24 hours $(\mathrm{ml})$ & $(n=15)$ & $(n=15)$ \\
(thirsting/no access to water) & & \\
Urine osmolalities (mOsm/kg $\left.\mathrm{H}_{2} \mathrm{O}\right)$ & $2,306 \pm 230$ & $1,041 \pm 121$ \\
$\quad$ Before thirsting & $(n=12)$ & $(n=24)$ \\
& $3,700 \pm 9^{\mathrm{A}}$ & $1,970 \pm 108^{\mathrm{A}}$ \\
After thirsting (24 hours) & $(n=12)$ & $(n=24)$ \\
& $3,320 \pm 103^{\mathrm{B}}$ & $1035 \pm 168$ \\
& $(n=10)$ & $(n=10)$ \\
Before dDAVP & $3,584 \pm 16^{\mathrm{A}}$ & $1,767 \pm 230^{\mathrm{A}}$ \\
& $(n=10)$ & $(n=10)$ \\
after dDAVPC &
\end{tabular}

Data are given as means \pm SEM ( $n=$ number of animals). ${ }^{A} P<0.05$; Student's $t$ test. In the water intake and urine output tests, comparisons are made between $V 2 R^{+/+}$and $V 2 R^{+/-}$values. In the urine concentrating tests, comparisons are made between preinjection (or prethirsting) and the corresponding postinjec-

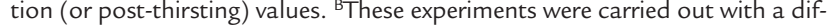
ferent set of mice about 1 year after the thirsting experiments. The reason for the relatively high basal urine osmolalities observed in this set of studies is not entirely clear. ${ }^{C}$ Urine samples were collected 2 hours after dDAVP injection. 


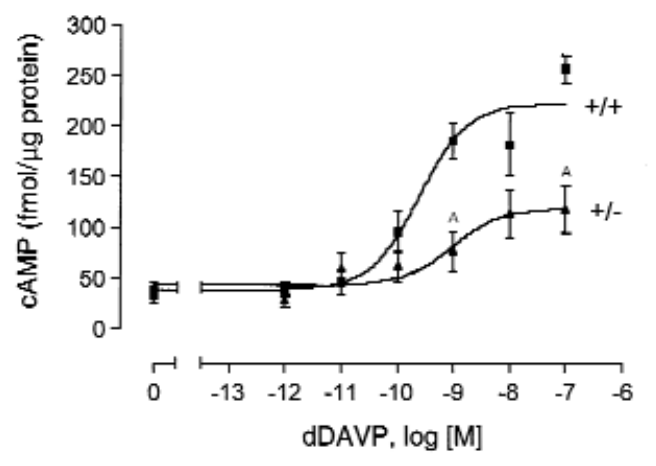

Figure 5

dDAVP-induced cAMP production in IMCD tubule suspensions. IMCD tubule suspensions were prepared from adult female mice of the indicated $V 2 R$ genotypes. dDAVP-induced increases in intracellular cAMP levels were determined as described in Methods. Data are given as means $\pm \operatorname{SEM}\left(n=5\right.$ for each genotype). ${ }^{A} P<0.01$ (Student's $t$ test).

used for immunization) did not reveal any labeling (data not shown). Semiquantitative analysis of immunogold labeling patterns revealed no statistically significant differences in the subcellular distribution and total labeling of AQP2 among wild-type and $V 2 R^{+/-}$ mutant mice (Table 5).

\section{Discussion}

In this study, we have used gene targeting technology to create mice that harbor a functional V2R null allele (Glu242stop) $(19,20) . V 2 R^{-1} y$ male mice died within the first week after birth, apparently due to hypernatremia and dehydration caused by the inability of these animals to concentrate their urine (Tables 1 and 2). Hypernatremic dehydration, caused by the loss of free water coupled with inadequate fluid intake, is also thought to be the primary cause of the key symptoms displayed by human infants suffering from XNDI (11-15). These symptoms include fever, vomiting, failure to thrive, and, at least in some cases, mental retardation (11-15).

Obviously, $V 2 R^{-1 y}$ mice die prematurely because they cannot adequately compensate for the urinary water losses. One possibility is that the thirst mechanisms that act as the primary stimulus for increased fluid intake are not yet fully developed in neonatal mice. Consistent with this notion, Hall and Browde (40) showed that dehydrated neonatal mice, in contrast to neonatal rats, showed little inclination to ingest liquids that were either spilled on the cage floor or offered through oral cannulas. Similarly, our attempts to hand-feed the $V 2 R^{-1 y}$ pups (e.g., with $5 \%$ dextrose or water) or to induce feeding by directing the pups to the mother's teats proved unsuccessful. It should be noted, however, that thirst mechanisms appear to be intact in newborn babies with XNDI (16).

In an attempt to prolong the life span of the $V 2 R^{-/ y}$ pups, we therefore decided to inject these animals with $5 \%$ dextrose solution $(0.3 \mathrm{ml} / \mathrm{g}$ daily, subcutaneously), starting from postnatal day 1 . This strategy increased the life span of the $V 2 R^{-/ y}$ pups by about three- to four- fold (average life span: 13.7 days; Table 3). Coinjection of HCT $(50 \mathrm{mg} / \mathrm{kg} / \mathrm{d}$, subcutaneously), a drug commonly used in the treatment of XNDI (13-15), did not lead to an additional significant increase in average survival time (16.5 days; Table 3). Systematic variation of drug doses and injection protocols, including perhaps changes in air humidity and ambient temperature, might prove useful to increase further the life span of the $V 2 R^{-1 y}$ mice.

Histological analysis revealed that the renal pelvis of 3-day-old $V_{2} \mathrm{R}^{-1 y}$ mice was significantly increased in size (Figure 3). This dilatation of the kidney pelvis, which can also result from other polyuric conditions (see ref. 41 and references therein), is most likely caused by the production of large amounts of urine surpassing the drainage capacity of the ureters (functional obstruction), resulting in an increase in pelvic pressure and ultimately pelvis dilatation. Consistent with our findings, it is known that human patients with XNDI frequently suffer from hydronephrosis due to prolonged polyuria in the absence of any morphological urinary obstruction $(41,42)$. The term bydronephrosis is generally used to define a condition characterized by a progressive dilatation of the renal pelvis, usually associated with the destruction or atrophy of renal medullary tissue and an increased incidence of chronic kidney failure $(41,42)$.

Independent of $V 2 R$ genotype, basal urine osmolalities were found to be considerably lower in 3-day-old
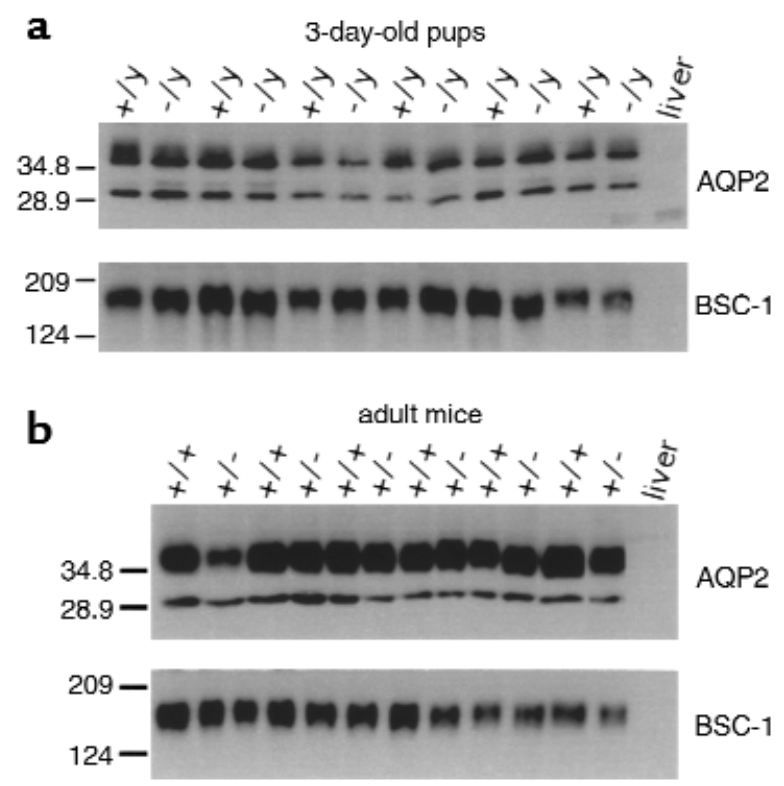

Figure 6

Western blotting analysis of AQP2 and BSC-1 expression in $V 2 R$ mutant mice. Whole kidney membrane preparations were obtained from 3-day-old pups (a) or adult female mice (b) of the indicated $V 2 R$ genotypes. Each lane contained equal amounts of protein (10 $\mu \mathrm{g})$ prepared from different animals. Mouse liver tissue served as a negative control. Immunoblotting experiments were carried out as described in Methods. AQP2 and BSC-1 were detected by specific rabbit polyclonal antibodies $(30,31)$. Duplicate gels were stained with Coomassie blue to confirm equal loading of samples. Two additional experiments gave similar results. 

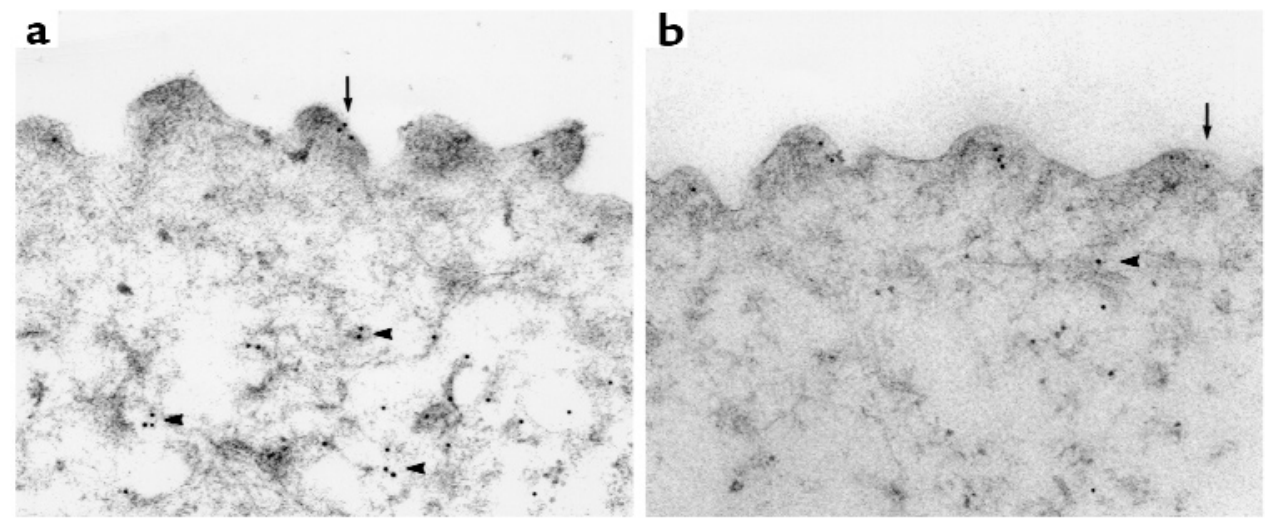

\section{Figure 7}

Immunoelectron microscopical localization of AQP2 in IMCD principals cells prepared from kidneys of adult female mice. Independent of $V 2 R$ genotype $\left(\mathbf{a}, V 2 R^{+/+} ; \mathbf{b}, V 2 R^{+/-}\right)$, AQP2 immunogold labeling is associated with the apical plasma membrane (arrows) and intracellular vesicles (arrowheads). Each panel shows the apical part of one IMCD principal cell. A semiquantitative analysis of immunogold labeling patterns is given in Table $5 . \times 63,000$.

pups $(<500 \mathrm{mOsm} / \mathrm{kg})$ than in adult mice $(>1,500$ $\mathrm{mOsm} / \mathrm{kg})$ (Tables 1 and 4$)$. This observation is consistent with previous findings that the urine-concentrating ability of the neonate kidney is limited (reviewed in ref. 33). A variety of factors, both structural and functional in nature, are thought to account for this phenomenon (33). At a molecular level, the observed low sensitivity of the neonatal renal collecting duct system to the biochemical and physiological actions of AVP appears to correlate directly with very low renal V2R densities $(33,43)$. Consistent with this notion, we were unable to detect significant numbers of specific $\left[{ }^{3} \mathrm{H}\right]$ AVP binding sites even in wild-type pups ( 3 days old), suggesting that the number of V2Rs present in the kidneys of neonatal mice is below the detection limit of our radioligand binding assay $(\sim 3 \mathrm{fmol} / \mathrm{mg})$.

Interestingly, adult female $V 2 R^{+/-}$mice showed clear symptoms of XNDI, including reduced urine-concentrating ability, polyuria, and polydipsia (Table 4). However, we also noted that the severity of these symptoms varied considerably among individual mice (Table 4).
In humans, female carriers of a $V 2 R$ mutation also show a high degree of phenotypic variation, with the XNDI phenotype being either totally absent, partial, or complete (44-46). It has been proposed that a pronounced XNDI phenotype in heterozygous females is due to skewed $X$-inactivation (44-46) in which the wild-type $V 2 R$ allele is preferentially inactivated (normally, inactivation of one of the two X chromosomes in females is a random process). It remains to be studied whether skewed X-inactivation also contributes to the phenotypic variation observed with adult $V_{2} \mathrm{R}^{+/-}$ mice. However, because the number of detectable V2R $\left(\left[{ }^{3} \mathrm{H}\right] \mathrm{AVP}\right)$ binding sites in the kidneys of $V 2 \mathrm{R}^{+/-}$mice did not show drastic variations, other factors may be involved in the expression of the XNDI phenotype in these animals. Given that the renal V2R density is quite low even in wild-type mice $\left(B_{\max }=29 \pm 4 \mathrm{fmol} / \mathrm{mg}\right)$, the additional loss of $50 \%$ of V2Rs in the $V 2 R^{+/-}$mice $\left(\mathrm{B}_{\max }\right.$ $=16 \pm 3 \mathrm{fmol} / \mathrm{mg}$ ) may represent the major factor leading to the manifestation of the XNDI phenotype. It should be noted that renal V2R densities are known to

Table 5

Semiquantitative analysis of immunogold labeling for AQP2 in the apical part of IMCD principal cells from adult female mice of the indicated $\mathrm{V} 2 \mathrm{R}$ genotypes

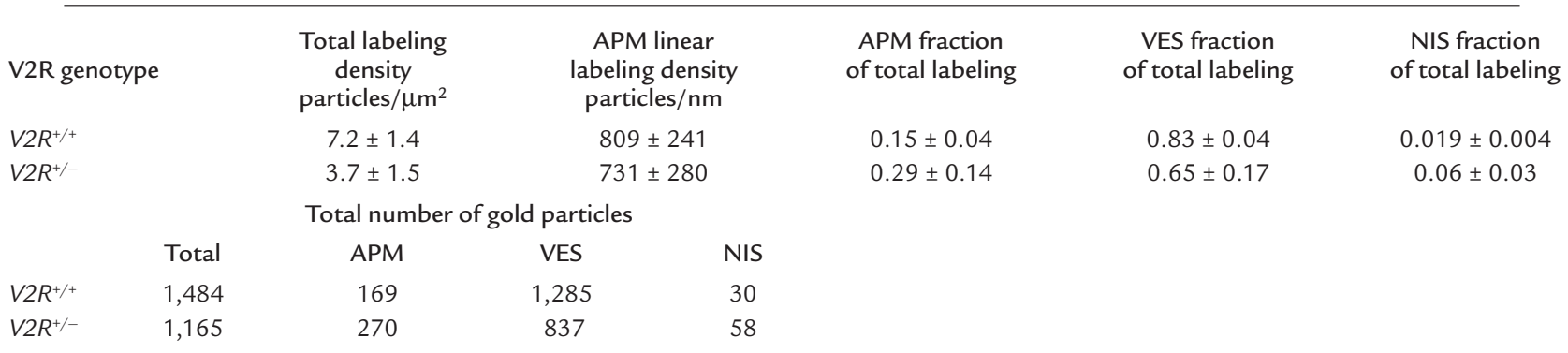

Values are means \pm SEM (three mice per genotype). Total labeling density refers to the total density of gold particles per area cytoplasm. Apical plasma membrane (APM) linear labeling density refers to the number of gold particles per length APM. Values in the last three columns are expressed as fraction of total labeling of the APM, intracellular vesicles (VES), and nonidentifiable structures (NIS). NIS refers to structures that were not strictly identified as VES or APM (this is likely to represent labeling in tangentially sectioned vesicles or rough endoplasmic reticulum). The total number of gold particles represents the sum from three mice (counts were taken in areas of similar size). 
be considerable higher in many other species including human $(47,48)$. Interestingly, maximum increases in intracellular cAMP levels induced by the V2R agonist dDAVP were reduced by about $50 \%$ in IMCD tubule suspensions prepared from kidneys of $V 2 R^{+/-}$mice (Figure 5), providing a molecular correlate for the XNDI phenotype observed with the $V 2 R^{+/-}$mutant mice.

Recently, several different mutant mouse lines suffering from symptoms of nephrogenic diabetes insipidus (NDI) have been generated by the use of gene-targeting technology. It has been reported, for example, that mice lacking the aquaporin-1 (49) or aquaporin-3 (50) water channels or the CLC-K1 chloride channel (51) (these proteins are expressed in distinct segments of the renal tubules) exhibit severe urine-concentrating defects. In contrast to the $V 2 R^{-1} y$ mutant mice described here, these animals showed normal survival rates, suggesting that urine-concentrating ability was not completely lost in these mutant mice. The "DI +/+ severe" mouse strain also displays a pronounced NDI phenotype which appears to be caused by the overactivity of a rolipram-sensitive cAMP phosphodiesterase (52). It remains to be seen whether defects in the human counterparts of these genes play a role in certain forms of congenital NDI.

Several studies have shown that the expression levels of AQP2 (35-37) and BSC-1 (31), two membrane proteins that play key roles in urine concentration, are positively regulated by V2R activity. Whereas AQP2, the AVP-regulated water channel, is selectively expressed in renal collecting duct cells $(53,54)$, the BSC-1 Na-K-2Cl cotransporter is primarily expressed in cells of the thick ascending limb of Henle's loop (38). BSC-1 is thought to play a key role in establishing the corticomedullary osmotic gradient that is a prerequisite for efficient water reabsorption in the kidney $(2,55)$. An important question that can be addressed by the use of the $V 2 R$ mutant mice is to what extent the loss of functional V2Rs affects AQP2 and BSC-1 expression levels. Currently, no such information is available for patients with XNDI.

Semiquantitative immunoblotting studies showed that the complete absence of functional V2Rs (studied with $V 2 R^{-1 y}$ and $V 2 R^{+/ y}$ male pups) had no significant effect on basal AQP2 and BSC-1 expression levels (Figure 6a). Similar results were obtained when AQP2 and BSC-1 expression levels were compared among $V 2 R^{+/-}$ and $\mathrm{V} \mathrm{R}^{+/+}$adult female mice (Figure 6a). Moreover, immunoelectron microscopical studies showed that IMCD principal cells from adult $V 2 R^{+/-}$and $V 2 R^{+/+}$mice displayed no significant differences in the subcellular distribution or total labeling of AQP2 (Figure 7; Table 5 ). Taken together, these data indicate that high basal AQP2 and BSC-1 expression levels can be maintained even in the absence of functional V2Rs. It has been reported that treatment of rats with the V2R-selective antagonist OPC-31260 (corresponding to a "functional inactivation" of V2Rs) results in a significant decrease in AQP2 protein levels (56). One possible explanation for this discrepancy is that the $V 2 R$ mutant mice described here, as with patients suffering from XNDI, lack functional V2Rs throughout development. As a result, compensatory mechanisms may have evolved that allow the maintenance of proper basal AQP2 and BSC-1 expression levels.

In summary, we have generated an in vivo model that allows systematic physiological and molecular studies about how the loss of functional V2Rs affects kidney function. Clearly, the $V 2 R$ mutant mice described here represent an excellent tool to evaluate novel strategies for the treatment of XNDI, including gene therapeutic approaches (57).

\section{Acknowledgments}

We thank G. Miller, W. S. Young, and V. Foletta for their help with the histological analysis of the mouse kidneys, M.A. Knepper for providing us with the AQP2 and BSC-1 polyclonal antibodies, C. Li for expert technical assistance, $\mathrm{H}$. Westphal for providing the EIIa-cre mice, C. Paszty for supplying the pPN2T targeting vector, $\mathrm{D}$. Accili and $\mathrm{H}$. Westphal for advice and helpful discussions, and A.M. Spiegel for generous support of this work.

1. Jackson, E.K. 1996. Vasopressin and other agents affecting the renal conservation of water. In The pharmacological basis of therapeutics. 9th edition. J.G. Hardman and L.E. Limbird, editors. McGraw-Hill. New York, New York, USA. 715-731.

2. Skorecki, K.L., Brown, D., Ercolani, L., and Ausiello, D.A. 1992. Molecular mechanisms of vasopressin action in the kidney. In Handbook of physiology. Section 8: renal physiology. Volume 1. E.E. Windhager, editor. Oxford University Press. New York, New York, USA. 1185-1218.

3. Ostrowski, N.L., Young, W.S., III, Knepper, M.A., and Lolait, S.T. 1993. Expression of vasopressin V1a and V2 receptor messenger ribonucleic acid in the liver and kidney of embryonic, developing, and adult rats. Endocrinology. 133:1849-1859.

4. Marchingo, A.J., et al. 1988. Properties of $\left[{ }^{3} \mathrm{H}\right] 1$-desamino-8-D-arginine vasopressin as a radioligand for vasopressin $\mathrm{V}_{2}$-receptors in rat kidney. Endocrinology. 122:1328-1336.

5. Nielsen, S., Marples, D., Frokiaer, J., Knepper, M., and Agre, P. 1996. The aquaporin family of water channels in kidney: an update on physiology and pathophysiology of aquaporin-2. Kidney Int. 49:1718-1723.

6. Brown, D., Katsura, T., and Gustafson, C.E. 1998. Cellular mechanisms of aquaporin trafficking. Am. J. Physiol. 275:F328-F331.

7. Ward, D.T., Hammond, T.G., and Harris, H.W. 1999. Modulation of vasopressin-elicited water transport by trafficking of aquaporin2-containing vesicles. Annu. Rev. Physiol. 61:683-697.

8. Seibold, A., Brabet, P., Rosenthal, W., and Birnbaumer, M. 1992. Structure and chromosomal localization of the human antidiuretic hormone receptor gene. Am. J. Hum. Genet. 51:1078-1083.

9. Birnbaumer, M., et al. 1992. Molecular cloning of the receptor for human antidiuretic hormone. Nature. 357:333-335.

10. Lolait, S.J., et al. 1992. Cloning and characterization of a vasopressin V2 receptor and possible link to nephrogenic diabetes insipidus. Nature. 357:336-339.

11. Holtzman, E.J., and Ausiello, D.A. 1994. Nephrogenic diabetes insipidus: causes revealed. Hosp. Pract. 29:89-104.

12. Fujiwara, T.M., Morgan, K., and Bichet, D.G. 1995. Molecular biology of diabetes insipidus. Annu. Rev. Med. 46:331-343.

13. Bichet, D.G. 1998. Nephrogenic diabetes insipidus. Am. J. Med. 105:431-442.

14. Oksche, A., and Rosenthal, W. 1998. The molecular basis of nephrogenic diabetes insipidus. J. Mol. Med. 76:326-337.

15. Knoers, N.V.A.M., and Monnens, L.L.A.H. 1999. Nephrogenic diabetes insipidus. Semin. Nephrol. 19:344-352.

16. Crawford, J.D., and Bode, H.H. 1975. Disorders of the posterior pituitary in children. In Endocrine and genetic diseases of childhood and adolescence. L.I. Gardner, editor. W.B. Saunders Co. Philadelphia, Pennsylvania, USA. 126-158.

17. Holtzman, E.J., et al. 1993. Brief report: a molecular defect in the vasopressin V2-receptor gene causing nephrogenic diabetes insipidus. $N$. Engl. J. Med. 328:1534-1537. 
18. Knoers, N., and Monnens, L.A.H. 1990. Amiloride-hydrochlorothiazide versus indomethacin-hydrochlorothiazide in the treatment of nephrogenic diabetes insipidus. J. Pediatr. 117:499-502.

19. Wildin, R.S., Antush, M.J., Bennett, R.L., Schoof, J.M., and Scott, C.R. 1994. Heterogeneous AVPR2 gene mutations in congenital nephrogenic diabetes insipidus. Am. J. Hum. Genet. 55:266-277.

20. Schöneberg, T., Yun, J., Wenkert, D., and Wess, J. 1996. Functional rescue of mutant $\mathrm{V} 2$ vasopressin receptors causing nephrogenic diabetes insipidus by a coexpressed receptor polypeptide. EMBOJ. 15:1283-1291.

21. Morello, J.P., et al. 2000. Pharmacological chaperones rescue cell-surface expression and function of misfolded $\mathrm{V} 2$ vasopressin receptor mutants. J. Clin. Invest. 105:887-895.

22. Birnbaumer, M. 1995. ADH receptors: molecular biology and signal transduction. In Molecular nephrology. J.V. Bonventre and D. Schlondorff, editors. Marcel Dekker Inc. 517-524.

23. Paszty, C., et al. 1995 . Lethal $\alpha$-thalassaemia created by gene targeting in mice and its genetic rescue. Nat. Genet. 11:33-39.

24. Sauer, B. 1993. Manipulation of transgenes by site-specific recombination: use of Cre recombinase. Methods Enzymol. 225:890-900.

25. Deng, C., Wynshaw-Boris, A., Zhou, F., Kuo, A., and Leder, P. 1996 Fibroblast growth factor receptor 3 is a negative regulator of bone growth. Cell. 84:911-921.

26. Nagy, A., Rossant, J., Nagy, R., Abramow-Newerly, W., and Roder, J.C. 1993. Derivation of completely cell culture-derived mice from early-passage embryonic stem cells. Proc. Natl. Acad. Sci. USA. 90:8424-8428.

27. Munson, P.J., and Rodbard, D. 1980. LIGAND: a versatile computerized approach for characterization of ligand-binding systems. Anal. Biochem. 107:220-239.

28. Inoue, T., et al. 1998. Snap-23 in rat kidney: colocalization with aquaporin-2 in collecting duct vesicles. Am. J. Physiol. 275:F752-F760.

29. Ecelbarger, C.A., et al. 1997. Role of renal aquaporins in escape from vasopressin-induced antidiuresis in rat. J. Clin. Invest. 99:1852-1863.

30. DiGiovanni, S.R., Nielsen, S., Christensen, E.I., and Knepper, M.A. 1994 Regulation of collecting duct water channel expression by vasopressin in Brattleboro rat. Proc. Natl. Acad. Sci. USA. 91:8984-8988.

31. Kim, G.-H., et al. 1999. Vasopressin increases Na-K-2Cl cotransporter expression in thick ascending limb of Henle's loop. Am. J. Physiol. 276:F96-F103.

32. Frøkiaer, J., et al. 1999. Low aquaporin-2 levels in polyuric DI +/+ severe mice with constitutively high cAMP-phosphodiesterase activity. Am.J. Physiol. 276:F179-F190.

33. Spitzer, A., and Schwartz, G.J. 1992. The kidney during development. In Handbook of physiology. Section 8: renal physiology. Volume 1. E.E. Windhager, editor. Oxford University Press. New York, New York, USA. $475-544$.

34. Lakso, M., et al. 1996. Efficient in vivo manipulation of mouse genomic sequences at the zygote stage. Proc. Natl. Acad. Sci. USA. 93:5860-5865.

35. Knepper, M.A. 1997. Molecular physiology of urinary concentrating mechanisms: regulation of aquaporin water channels by vasopressin Am. J. Physiol. 272:F3-F12.

36. Deen, P.M.T., and Knoers, N.V.A.M. 1998. Physiology and pathophysiology of the aqaporin-2 water channel. Curr. Opin. Nephrol. Hypertens. 7:37-42

37. Frøkiaer, J., Marples, D., Knepper, M.A., and Nielsen, S. 1998. Pathophysiology of aqaporin-2 in water balance disorders. Am. J. Med. Sci. 316:291-299.

38. Nielsen, S., Maunsbach, A.B., Ecelbarger, C.A., and Knepper, M.A. 1998 Ultrastructural localization of $\mathrm{Na}-\mathrm{K}-2 \mathrm{Cl}$ cotransporter in thick ascend ing limb and macula densa of rat kidney. Am. J. Physiol. 275:F885-F893.
39. Baumgarten, R., Van De Pol, M.H.J., Wetzels, J.F.M., Van Os, C.H., and Deen, P.M.T. 1998. Glycosylation is not essential for vasopressin-dependent routing of aquaporin-2 in transfected Madin-Darby canine kidney cells. J. Am. Soc. Nephrol. 9:1553-1559.

40. Hall, W.G., and Browde, J.A., Jr. 1985. The ontogeny of independent ingestion in mice: or, why won't infant mice feed? Dev. Psychobiol. 19:211-222.

41.Zender, H.O., Ruedin, P., Moser, F., Bolle, J.-F., and Leski, M. 1992. Traumatic rupture of the urinary tract in a patient presenting nephrogenic diabetes insipidus associated with hydronephrosis and chronic renal failure: case report and review of the literature. Clin. Nephrol. 38:196-202

42. Uribarri, J., and Kaskas, M. 1993. Hereditary nephrogenic diabetes insipidus and bilateral nonobstructive hydronephrosis. Nephron. 65:346-349.

43. Rajerison, R.M., Butlen, D., and Jard, S. 1976. Ontogenic development of antidiuretic hormone receptors in rat kidney: comparison of hormonal binding and adenylate cyclase activation. Mol. Cell. Endocrinol. 4:271-285.

44. van Lieburg, A.F., et al. 1995. Clinical phenotype of nephrogenic diabetes insipidus in females heterozygous for a vasopressin type 2 receptor mutation. Hum. Genet. 96:70-78.

45. Moses, A.M., Sangani, G., and Miller, J.L. 1995. Proposed cause of marked vasopressin resistance in a female with an X-linked recessive V2 receptor abnormality. J. Clin. Endocrinol. Metab. 80:1184-1186.

46. Nomura, Y., et al. 1997. Detection of skewed X-inactivation in two female carriers of vasopressin type 2 receptor gene mutation. J. Clin. Endocrinol. Metab. 82:3434-3437.

47. Maggi, M., et al. 1989. Vasopressin receptors in human seminal vesicles: identification, pharmacologic characterization, and comparison with the vasopressin receptors present in the human kidney. J. Androl. 10:393-400.

48. Serradeil-Le Gal, C., et al. 1996. Characterization of SR 121463A, a highly potent and selective, orally active vasopressin V2 receptor antagonist. Clin. Invest. 98:2729-2738.

49. Ma, T., et al. 1998. Severely impaired urinary concentrating ability in transgenic mice lacking aquaporin-1 water channels. J. Biol. Chem. 273:4296-4299.

50. Ma, T., et al. 2000. Nephrogenic diabetes insipidus in mice lacking aquaporin-3 water channels. Proc. Natl. Acad. Sci. USA. 97:4386-4391.

51. Matsumura, Y., et al. 1999. Overt nephrogenic diabetes insipidus in mice lacking the CLC-K1 chloride channel. Nat. Genet. 21:95-98.

52. Valtin, H. 1992. Genetic models of diabetes insipidus. In Handbook of physiology. Section 8: renal physiology. Volume 1. E.E. Windhager, editor. Oxford University Press. New York, New York, USA. 1281-1316.

53. Fushimi, K., et al. 1993. Cloning and expression of apical membrane water channel of rat kidney collecting tubule. Nature. 361:549-552.

54. Nielsen, S., DiGiovanni, S.R., Christensen, E.I., Knepper, M.A., and Harris, H.W., Jr. 1993. Cellular and subcellular immunolocalization of vasopressin-regulated water channel in rat kidney. Proc. Natl. Acad. Sci. USA. 90:11663-11667.

55. Knepper, M.A., and Rector, F.J., Jr. 1995. Urine concentration and dilution. In The kidney. B.M. Brenner and F.J. Rector, Jr., editors. W.B. Saunders Co. Philadelphia, Pennsylvania, USA. 532-570.

56. Marples, D., Christensen, B.M., Frøkiaer, J., Knepper, M.A., and Nielsen, S. 1998. Dehydration reverses vasopressin antagonist-induced diuresis and aquaporin-2 downregulation in rats. Am. J. Physiol. 275:F400-F409.

57. Bichet, D.G., Oksche, A., and Rosenthal, W. 1997. Congenital nephrogenic diabetes insipidus. J. Am. Soc. Nephrol. 8:1951-1958. 